\title{
Assessment of Th17 lymphocytes and cytokine IL-17A in epithelial ovarian tumors
}

\author{
IZABELA WINKLER $^{1,4}$, MARIA PYSZNIAK $^{2,3}$, KATARZYNA POGODA $^{2,3}$, ANDRZEJ SEMCZUK $^{1}$, \\ MAREK GOGACZ ${ }^{1}$, PAWEŁ MIOTLA ${ }^{1}$, ANETA ADAMIAK ${ }^{1}$, DOROTA DARMOCHWAL-KOLARZ ${ }^{3}$, \\ TOMASZ RECHBERGER ${ }^{1}$ and JACEK TABARKIEWICZ ${ }^{3}$
}

\begin{abstract}
${ }^{1}$ Second Department of Gynecology, Lublin Medical University, 20-954 Lublin; ${ }^{2}$ Postgraduate School of Molecular Medicine, Warsaw Medical University, 02-091 Warsaw; ${ }^{3}$ Centre for Innovative Research in Medical and Natural Sciences, Medical Faculty of the University of Rzeszów, 35-959 Rzeszów; ${ }^{4}$ St. John's Oncology Center in Lublin, 20-090 Lublin, Poland
\end{abstract}

Received October 10, 2016; Accepted December 19, 2016

DOI: $10.3892 /$ or.2017.5559

\begin{abstract}
The present study was carried out to assess the percentage of T helper 17 (Th17) lymphocytes in blood and tissue and IL-17A serum concentrations in patients with epithelial ovarian tumors. Two isoforms, IL-17A and IL-17F, as well as IL-21 and IL-22, were simultaneously investigated. The study group consisted of 60 women affected by epithelial ovarian tumors (benign, borderline and malignant) and 20 women without ovarian pathology as a control group. The evaluation of the percentage of Th17 cells secreting IL-17A, IL-17F, IL-21 and IL-22 in peripheral blood and tumor tissues was performed using flow cytometry applying a Th17 cytokine staining panel. The blood serum concentration of IL-17A was determined using ELISA. We found no statistically significant differences in the subpopulations of Th17 lymphocytes, either in peripheral blood or in ovarian tissues, following comparison of the women with and without ovarian pathology. Negative correlations were found between the percentage of $\mathrm{CD}^{+} /$ $\mathrm{IL}^{2} 1^{+}\left(\mathrm{r}_{\mathrm{s}}=0.8, \mathrm{p}=0.02\right)$ and $\mathrm{CD} 4^{+} / \mathrm{IL}-17^{+}\left(\mathrm{r}_{\mathrm{s}}=-0.78, \mathrm{p}=0.03\right)$ in the tissue and IL-17A in blood serum in the group of patients with borderline ovarian tumors. A negative correlation was also found between IL-17A and the percentage of $\mathrm{CD} 4^{+} / \mathrm{IL}^{-2} 1^{+}$ in peripheral blood $\left(r_{s}=-0.48, p=0.03\right)$ in the group of patients with ovarian cancer. The increased percentage of Th17 cells in tissue was not correlated with the overall survival of the
\end{abstract}

Correspondence to: Dr Izabela Winkler, Second Department of Gynecology, St. John's Oncology Center in Lublin, 20-090 Lublin, Poland

E-mail: ikochans@interia.pl

Abbreviations: BOT, borderline tumor; CCR6, CC chemokine receptor; CCL20, CC chemokine ligand 20, CXCR3, CXC chemokine receptor; IL, interleukin; NK cells, natural killer cells; TGF- $\beta$, transforming growth factor- $\beta$; Tregs, lymphocyte $\mathrm{T}$ regulatory cells; Th17 lymphocytes, T helper 17 lymphocytes

Key words: IL-17A, IL-17F, IL-21, IL-22, ovarian cancer, ovarian cysts ovarian cancer patients. In conclusion, we showed that more Th17 cells secreted IL-17A and IL-21 in the tissue of borderline ovarian tumors and less IL-17A in serum. We also observed that in peripheral blood of the patients with ovarian cancer, there was a higher percentage of Th17 lymphocytes and a lower concentration of IL-17A in serum indicating a negative correlation. An increased percentage of Th17 cells in ovarian tissue does not influence the time of survival of patients with ovarian cancer.

\section{Introduction}

Th17 lymphocytes are a $\mathrm{T}$ helper cell population that play a crucial role in the immune response. The name of these cells originates from the secretion of cytokine IL-17 by these cells (1). They diverge from innate $\mathrm{CD}^{+} \mathrm{T}$ cells in the presence of transforming growth factor- $\beta$ (TGF- $\beta$ ) and IL-6 (1). IL-17A and IL-17F are the major cytokines secreted by Th17 cells. They are highly homogeneous, bind to the same receptor and have similar biological activities (2). These cytokines are also involved in the development of antibacterial and anti-inflammatory responses (2). In contrast, IL-17F is a weak inducer of the expression of proinflammatory cytokines and it is produced by a wide spectrum of immune cells (2).

Th17 lymphocytes also secrete interleukin (IL)-21 and IL-22. IL-21 enhances the expression of perforin, granzyme B, IFN- $\gamma$, CXCR3 peripheral NK cells and CD8 ${ }^{+}$lymphocytes, which reinforces an antitumor response (3). The expression of IL-22 inhibits TGF- $\beta(4,5)$. The protective role of IL-22 in inflammatory diseases is associated with the induction of the expression of $\beta$-defensins and lipocalin-2 (6,7).

In the present study, we assessed the proportion of Th17 cells secreting IL-17A, IL-17F, IL-21 and IL-22 in peripheral blood and in the microenvironment of benign, borderline (BOT) and malignant epithelial ovarian tumors. We examined the relationship between the percentage of $\mathrm{CD}^{+} / \mathrm{IL}-17 \mathrm{~A}^{+} \mathrm{F}^{+}$, $\mathrm{CD}^{+} / \mathrm{IL}_{-}-21^{+}$and $\mathrm{CD} 4^{+} / \mathrm{IL}-22^{+}$Th17 cells in the peripheral blood and ovarian tissues and the IL-17A serum concentrations. In the present study, we investigated not only two isoforms, IL-17A and IL-17F, but also IL-21 and IL-22. To 


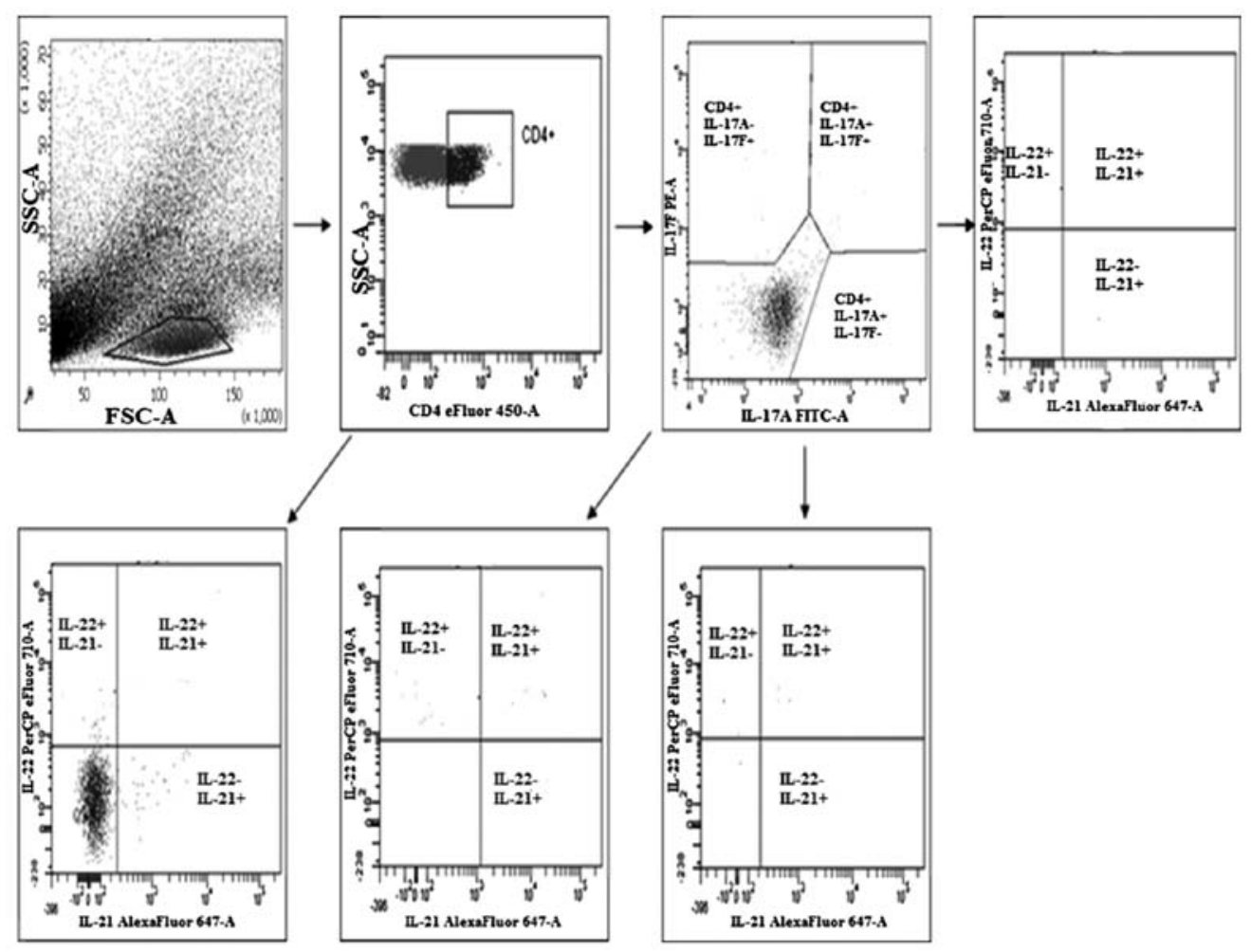

Figure 1. Example of flow cytometric analysis of Th17 cell subpopulations infiltrating the tumor tissue. Based on the parameters of the FSC, showing the cell size and SSC, showing the granularity-lymphocytic cells, the gate was set. In the second step of analysis, CD4 $4^{+}$lymphocytes were gated, including an analysis

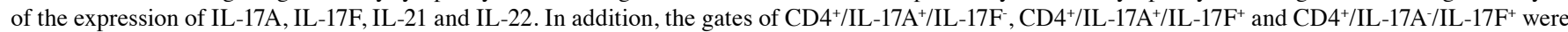
analyzed for coexpression of IL-21 and IL-22.

clarify the percentage of Th17 cells we conducted a study to determinate whether Th17 cells and IL-17A may be applied as prognosticators in patients affected by ovarian carcinomas.

\section{Materials and methods}

Research subjects and samples. The study group consisted of 60 women. The patients were subdivided into 3 groups: a group of 24 women with malignant epithelial ovarian tumors (cystadenocarcinoma), 25 women with benign ovarian tumors (cystadenoma), and 11 women with serous borderline tumors (BOTs). The control group consisted of 20 women without ovarian pathology, undergoing surgery due to urinary incontinence. All women with ovarian cancer had stage III or IV tumors according to FIGO (International Journal of Gynecology and Obstetrics, January, 2014). The study samples included blood serum, peripheral blood, ovarian tissues without pathology and tissues of malignant and benign tumors of the ovary. The study was approved by the Bioethics Committee of the Medical University of Lublin (KE-0254/90/2011). The patients gave their written consent before they participated in the present study.

Isolation of mononuclear cells from peripheral blood (PBMCs). Immediately after bloood was taken from the anticubital vein, peripheral blood mononuclear cells (PBMCs) were isolated by density gradient centrifugation using Gradisol L formulation at a specific density of $1.077 \mathrm{~g} / \mathrm{ml}$ (Aqua Medica, Łódź, Poland) for $20 \mathrm{~min}$ at $700 \mathrm{x} \mathrm{g}$. The pellet containing the PBMCs was washed twice in phosphate-buffered saline (PBS) and evaluated for the number (using Neubauer chamber) and viability (trypan blue staining-0.4\% trypan blue solution; Sigma-Aldrich, Munich, Germany). Viability of $<95 \%$ was a disqualifying criteria for conducting further research.

Isolation of mononuclear cells infiltrating tumor and healthy tissues. During surgery, fragments of ovarian tumor not containing necrotic areas (the size of $1 \mathrm{~cm}^{3}$ ) or healthy ovarian tissue were collected and minced with a scalpel. The minced tissue was suspended in $30 \mathrm{ml}$ of RPMI-1640 medium (Biochrom, Holliston, MA, USA) and subjected to digestion in a mixture containing $1 \mathrm{mg} / \mathrm{ml}$ collagenase type IA, $1 \mathrm{mg} /$ $\mathrm{ml}$ DNase type I, $0.1 \mathrm{mg} / \mathrm{ml}$ hyaluronidase (all from SigmaAldrich) at $37^{\circ} \mathrm{C}$ for $60 \mathrm{~min}$, and constantly vortexed. After digestion, the suspension was filtered through a strainer (70 $\mu \mathrm{m}$; BD Biosciences, San Jose, CA, USA) and centrifuged for $5 \mathrm{~min}$ at $700 \mathrm{x}$ g. The cell suspension was washed twice in RPMI-1640 medium.

Evaluation of the percentage of Th17 cells. The evaluation of the percentage of Th17 cells (secreting IL-17A, IL-17F, IL-21 and IL-22) in the PBMCs, healthy tissue and tumor tissue was performed by flow cytometry using a Th17 cytokine staining panel according to the manufacturer's recommendations using a FACSCanto (both from BD Biosciences) (Fig. 1).

Establishment of PBMC culture and ovarian tissues (tumor or control) and stimulation with ionomycin. A 24-h culture of the PBMCs and ovarian tissue was set-up. The medium was 
Table I. Demographic and clinical characteristics of the study groups.

\begin{tabular}{lrrrr}
\hline $\begin{array}{l}\text { Group of } \\
\text { patients }\end{array}$ & $\begin{array}{c}\text { Controls group } \\
(\mathrm{n}=20)\end{array}$ & $\begin{array}{c}\text { Benign tumors } \\
(\mathrm{n}=25)\end{array}$ & $\begin{array}{r}\text { Borderline tumors } \\
(\mathrm{n}=11)\end{array}$ & $\begin{array}{r}\text { Ovarian cancers } \\
(\mathrm{n}=24)\end{array}$ \\
\hline Age $(\mathrm{years})$ & $50(37-78)$ & $55(32-85)$ & $47(35-77)$ & $55(44-80)$ \\
BMI $\left(\mathrm{kg} / \mathrm{m}^{2}\right)$ & $28(21-36.7)$ & $26(11.9-46.7)$ & $31.6(17.9-45.7)$ & $25.6(25-35.2)$ \\
Gravidity $(\mathrm{n})$ & $2(0-4)$ & $2(0-7)$ & $2(0-5)$ & 0.400 \\
Leukocytes $10^{3}$ cells $/ \mu 1$ & $7.2(4.17-11.8)$ & $5.8(3-21)$ & $7.2(5-10.8)$ & $7.3(3.58-13.5)$ \\
\hline
\end{tabular}

Data are expressed as median (range). Kruskall-Wallis test was used for statistical analysis. BMI, body mass index.

prepared consisting of 97\% RPMI-1640 (Biochrom) supplemented with $2 \mathrm{mM}$ L-glutamine, $2 \%$ human albumin (ZLB Bioplasma, Bern, Switzerland), and antibiotics in an amount of $100 \mathrm{U} / \mathrm{ml}$ penicillin and $100 \mathrm{mg} / \mathrm{ml}$ streptomycin (both from Sigma-Aldrich). Cultivation was carried out in 6-well plates in a 5-ml culture medium. For each patient, two cultures were established, one from the PBMCs and the other from the tumor cells or normal ovarian tissue. The culture was conducted in an incubator under standard conditions $\left(5 \% \mathrm{CO}_{2}, 95 \%\right.$ humidity, $37^{\circ} \mathrm{C}$ ) for $4 \mathrm{~h}$. To individual wells, ionomycin at a concentration of $1 \mu \mathrm{g} / \mathrm{ml}$ and PMA at a concentration of $25 \mathrm{ng} / \mathrm{ml}$ were added to stimulate cells for the production of cytokines and brefeldin at a concentration $10 \mu \mathrm{g} / \mathrm{ml}$ (both from Sigma-Aldrich) in order to inhibit the activity of the endoplasmic reticulum, leading to retain the cytokines within the cell.

Determination of intracellular cytokines. The 24-h cultures were moved from the culture plate to two properly signed tubes and were washed twice in $2 \mathrm{ml}$ of Flow Cytometry Staining Buffer (eBioscience, San Diego, CA, USA) after vortexing. The constant parameters used during each rinsing in this procedure consisted of: run time $5 \mathrm{~min}$, $700 \mathrm{x}$ g. After removal of the supernatant, $5 \mu \mathrm{l}$ of anti-CD4 (eFluor 450; eBioscience) was added to each tube. The mixture was incubated for $20 \mathrm{~min}$ in darkness. After washing, the excess of antibody in $2 \mathrm{ml}$ of Flow Cytometry Staining Buffer, $100 \mu 1$ IC Fixation Buffer (both from eBioscience) was added to each tube in order to consolidate. Mixing/vortexing, this mixture was also incubated for $20 \mathrm{~min}$ in darkness. Then, it was washed twice with $2 \mathrm{ml}$ of the permeabilization buffer (eBioscience). Preparing the buffer involved a 10-fold dilution with PBS. After removing the supernatant, the cells were resuspended in $100 \mu \mathrm{l}$ of permeabilization buffer and separated to previously prepared cytometry tubes into control and test samples. Thereafter, $5 \mu \mathrm{l}$ of the antibodies was added to the test samples: anti-IL-17A (FITC), anti-IL-17F (PE), anti-IL-21 (eFluor 660), anti-IL-22 (PerCP-eFluor 710). After vortexing, all samples were incubated for $20 \mathrm{~min}$ in darkness. They were washed twice. After the cells were suspended in the Flow Cytometry Staining Buffer, cytometric analysis was carried out. Analysis was performed using flow cytometric 8-channel BD FACSCanto II (BD Biosciences, San Diego, CA, USA). Measurements were performed using BD FACSDiva software.

Evaluation of the IL-17A cytokine level. The concentration of IL-17A was determined by ELISA. Quantikine ${ }^{\circledR}$ Human IL-17 ELISA kit (cat. no. D1700; R\&D Systems, Minneapolis, MN,
USA) was applied. The procedure was performed according to the manufacturer's instructions, and an automatic Victor3 reader (PerkinElmer, Inc., Waltham, MA, USA) was utilized.

Statistical analysis. Non-parametric and Kruskal-Wallis tests were used to verify the differences between the studied groups, post hoc (Dunn) to assess the internal differences between 2 groups, Wilcoxon matched pairs signed-rank for comparing the value of the parameter pairs and Spearman's rank correlation coefficient and its validity to assess the correlation between the two parameters. Kaplan-Meier analysis was used to compare survival curves depending on the range of the percentage of $\mathrm{CD} 4^{+} / \mathrm{IL}-17^{+}$and concentration of IL-17A. Overall survival was defined as the interval between the date of surgery and the last follow-up or date of death. P-values $<0.05$ were considered significant. Statistical analysis was performed using 10.0 PL Statistics for Windows (StatSoft, Inc., Tulsa, OK, USA).

\section{Results}

Study group. There was no differences in age $(\mathrm{p}=0.4)$, body mass index $(B M I)(p=0.053)$, gravidity $(p=0.46)$ or the concentration of leukocytes in the peripheral blood $(\mathrm{p}=0.29)$ of all the study groups (Table I).

Assessment of Th17 lymphocyte subpopulation in the peripheral blood. The number of Th17 cells in peripheral blood was decreased in the ovarian cancer patients as compared to the other study groups. We found no significant differences in the percentage of $\mathrm{CD}^{+} / \mathrm{IL}-17 \mathrm{~A}^{+} / \mathrm{IL}^{+} 17 \mathrm{~F}^{-}(\mathrm{p}=0.5)$

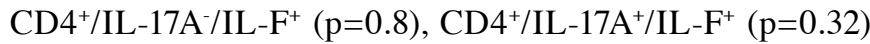
and $\mathrm{CD} 4^{+} / \mathrm{IL}-17^{+*}(\mathrm{p}=0.4)$ Th17 cells in the peripheral blood among the study groups (Table II). ${ }^{*} \mathrm{CD} 4^{+} / \mathrm{IL}-17^{+}$is the sum of the percentages of $\mathrm{CD}^{+} / \mathrm{IL}-17 \mathrm{~A}^{+} / \mathrm{IL}^{-17 \mathrm{~F}^{-}}, \mathrm{CD}^{+} / \mathrm{IL}-17 \mathrm{~A}^{-} /$ IL-17F ${ }^{+}$and $\mathrm{CD} 4^{+} / \mathrm{IL}-17 \mathrm{~A}^{+} / \mathrm{IL}-17 \mathrm{~F}^{+}$Th17 cells.

Percentage of Th17 cells in the ovarian tumor tissue. The amount of Th17 cells in ovarian tissue was slightly increased in the ovarian cancer patients compared to that noted in the other groups. There were no significant differences in the percentage

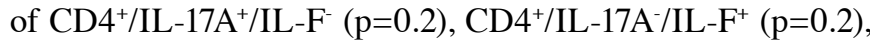

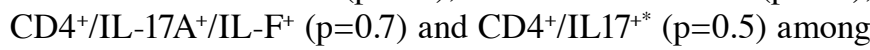
the group of patients (Table III). ${ }^{*} \mathrm{CD} 4^{+} / \mathrm{IL}-17^{+}$is the sum of the percentages of $\mathrm{CD}^{+} / \mathrm{IL}-17 \mathrm{~A}^{+} / \mathrm{IL}^{-17 \mathrm{~F}^{-}}, \mathrm{CD}^{+} / \mathrm{IL}-17 \mathrm{~A}^{-} / \mathrm{IL}-17 \mathrm{~F}^{+}$ and $\mathrm{CD}^{+} / \mathrm{IL}-17 \mathrm{~A}^{+} / \mathrm{IL}-17 \mathrm{~F}^{+}$Th17 cells. 
Table II. Percentage of CD4 ${ }^{+}$Th17 cells in the peripheral blood of the study groups.

\begin{tabular}{llrrr}
\hline Groups & $\mathrm{n}$ & $\mathrm{IL}-17 \mathrm{~A}^{+} / \mathrm{IL}-17 \mathrm{~F}^{-}$ & $\mathrm{IL}-17 \mathrm{~A}-/ \mathrm{IL}-17 \mathrm{~F}^{+}$ & $\mathrm{IL}^{+}-17 \mathrm{~A}^{+} / \mathrm{IL}^{-17 F^{+}}$ \\
\hline Control group & 20 & $0.5(0-2.6)$ & $0.6(0-3.3)$ & $0.6(0,20.0)$ \\
Benign tumors & 25 & $0.5(0-8.7)$ & $0.45(0-8.7)$ & $0.75(0-30.4)$ \\
Borderline tumors & 11 & $0.55(0.2-2.0)$ & $0.4(0-0.8)$ & $0.65(0,1-10.1)$ \\
Ovarian cancers & 24 & $0.4(0-1.7)$ & $0.2(0-14.1)$ & $0.2(0-4.0)$
\end{tabular}

Data are expressed as median (range).

Table III. Percentage of Th17 cells in ovarian tissues of the study groups.

\begin{tabular}{|c|c|c|c|c|}
\hline Groups & $\mathrm{n}$ & $\mathrm{IL}-17 \mathrm{~A}^{+} / \mathrm{IL}-17 \mathrm{~F}^{-}$ & IL-17A-/IL-17F $\mathrm{F}^{+}$ & $\mathrm{IL}-17 \mathrm{~A}^{+} / \mathrm{IL}-17 \mathrm{~F}^{+}$ \\
\hline Control group & 20 & $0.15(0-4.2)$ & $0(0-3.3)$ & $21.9(0.1-52.5)$ \\
\hline Benign tumors & 25 & $1.3(0-7.0)$ & $0.25(0-11.8)$ & $13.2(0.2-64.9)$ \\
\hline Borderline tumors & 11 & $0.1(0-3.9)$ & $1.0(0-4.5)$ & $7.7(0.4-31.2)$ \\
\hline Ovarian cancers & 24 & $0.8(0-10)$ & $1.5(0-14.3)$ & $14.1(0.2-46.2)$ \\
\hline
\end{tabular}

Data are expressed as median (range).
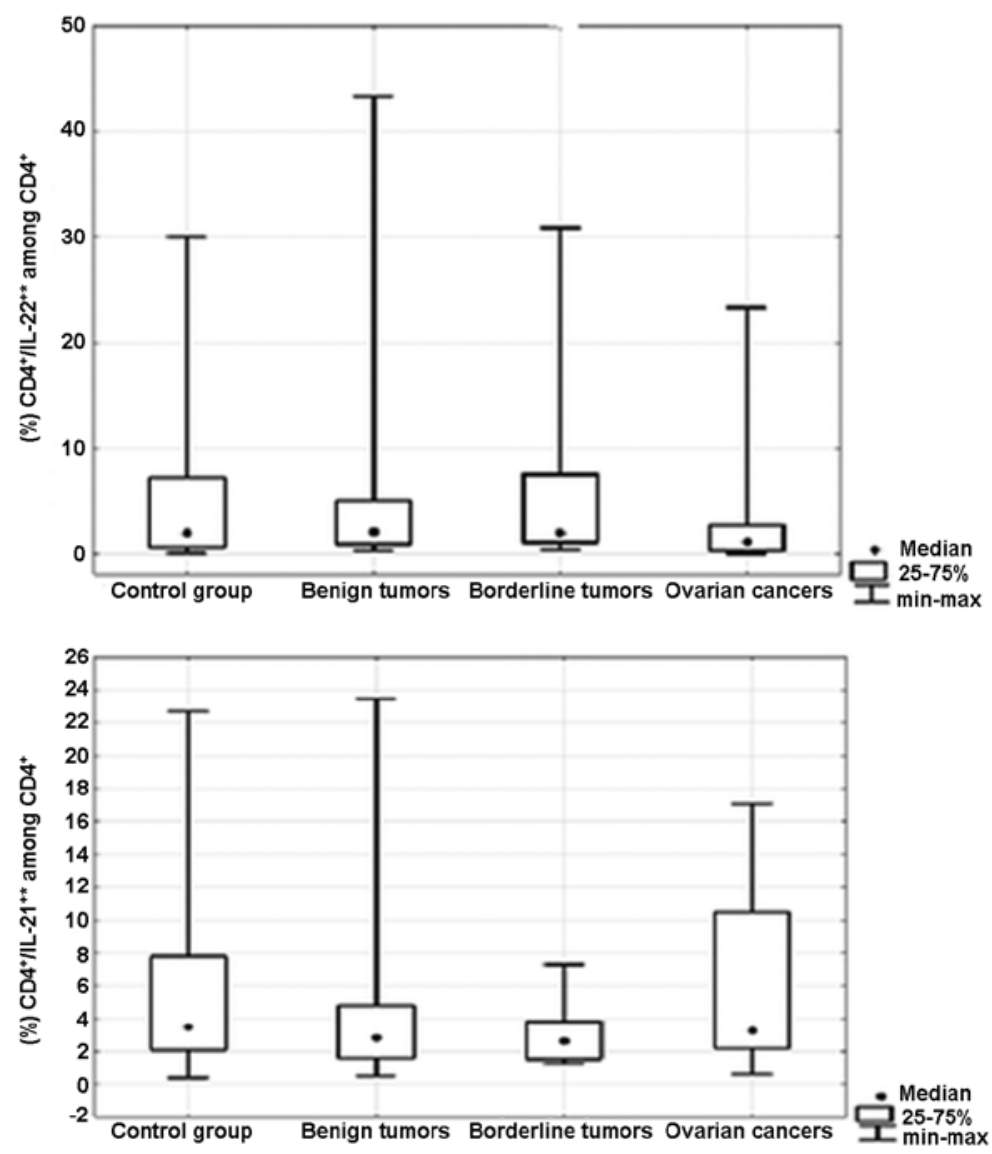

Figure 2. Percentage of $\mathrm{CD} 4^{+} / \mathrm{IL}-21^{+*}$ and $\mathrm{CD} 4^{+} / \mathrm{IL}-22^{+*}$ in the peripheral blood of the study groups of patients with epithelial ovarian tumors. "CD4 ${ }^{+} \mathrm{IL}-21^{+}$ is the sum of the percentages of $\mathrm{CD} 4^{+} / \mathrm{IL}-21^{+} / \mathrm{IL}-22^{-}$and $\mathrm{CD} 4^{+} / \mathrm{IL}-21^{+} / \mathrm{IL}-22^{+} ;{ }^{*} \mathrm{CD} 4^{+} / \mathrm{IL}-22^{+}$is the sum of the percentages of $\mathrm{CD}^{+} / \mathrm{IL}^{-2} 1^{-} / \mathrm{IL}-22^{+}$and $\mathrm{CD} 4^{+} /$ IL- $21^{+} / \mathrm{IL}-22^{+}$cells.

Percentage of Th17 cells secreting IL-21 and/or IL-22 in the peripheral blood and ovarian tumor tissues. There were no significant differences in the percentage of $\mathrm{CD} 4^{+} / \mathrm{IL}-21^{+*}$ $(\mathrm{p}=0.5)$ and $\mathrm{CD}^{+} / \mathrm{IL}-22^{+*}(\mathrm{p}=0.5)$ Th17 cells in the peripheral 

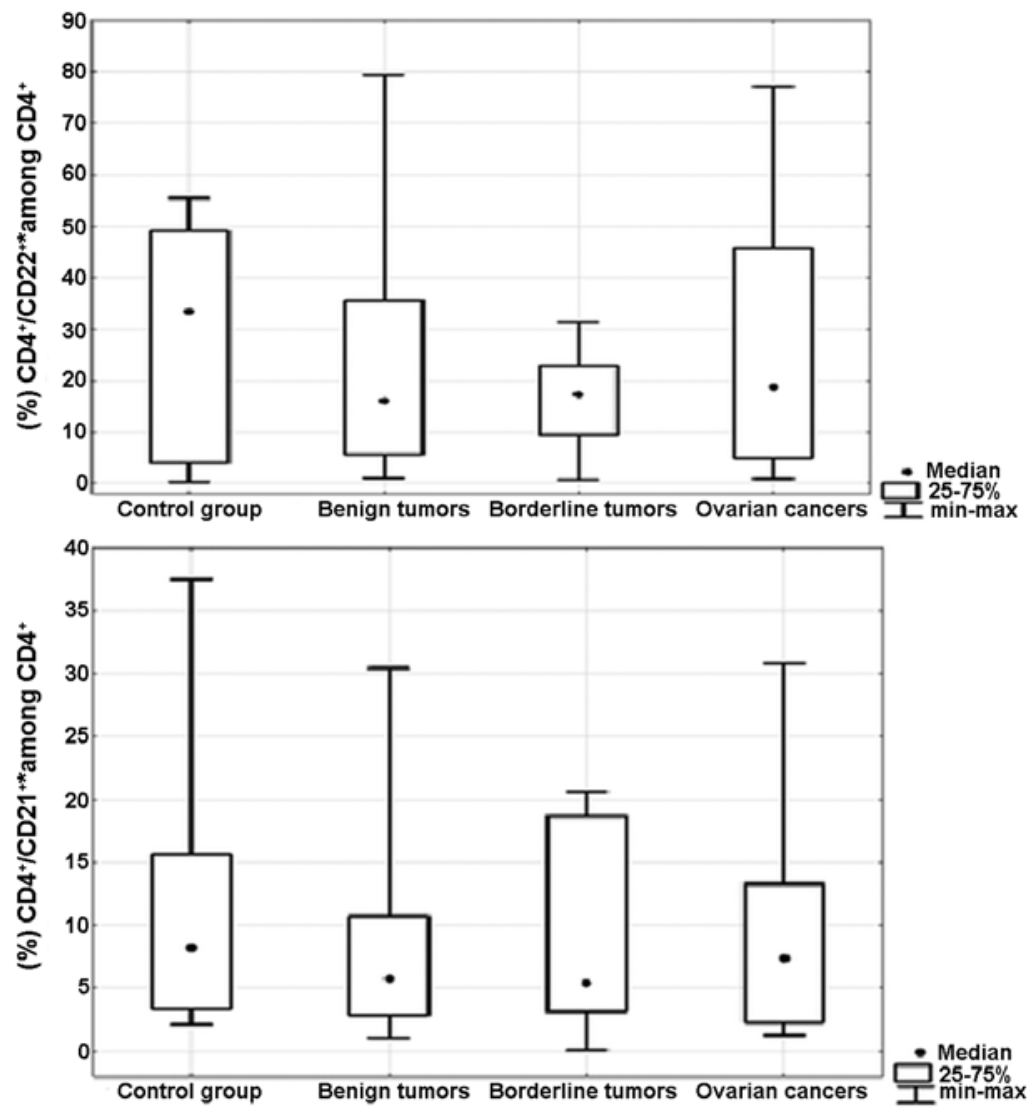

Figure 3. Percentage of the Th17 cells secreting IL-21 or/and IL-22 in epithelial ovarian tissues. ${ }^{*} \mathrm{CD} 4^{+} \mathrm{IL}-21^{+}$is a sum of the percentages of $\mathrm{CD} 4{ }^{+} / \mathrm{IL}-21^{+} /$

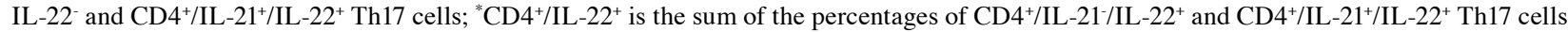
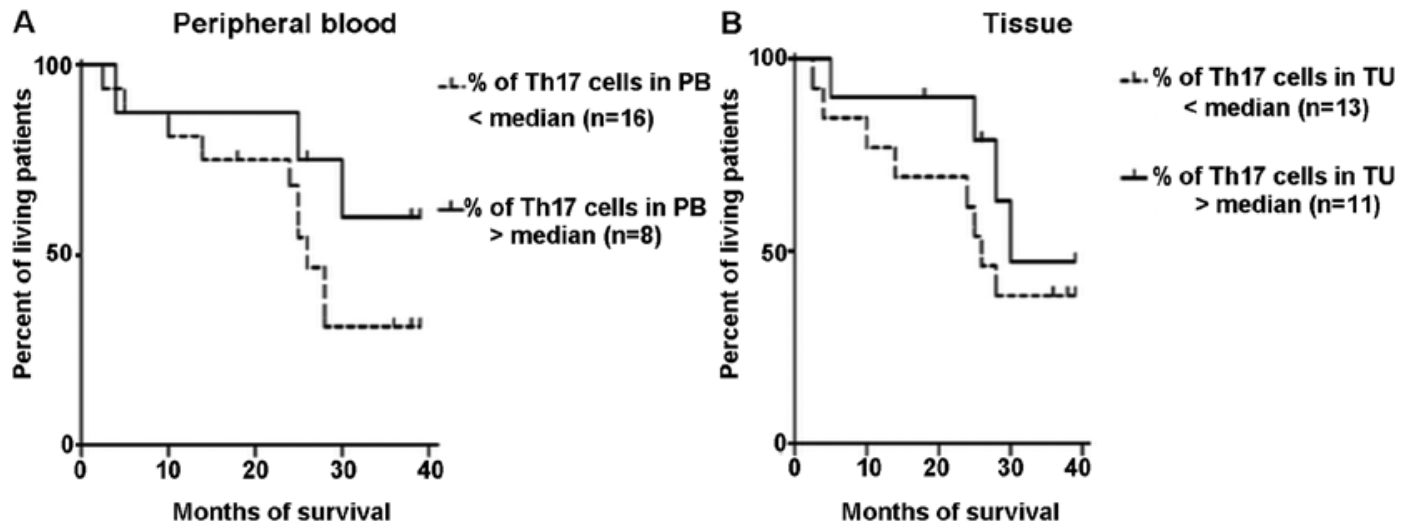

Figure 4. Kaplan-Meier survival curves dependent on the percentage of Th17 cells in (A) the peripheral blood (PB) and (B) tissue (TU) of ovarian cancer patients. Peripheral blood; median, $1.6 \%, \mathrm{p}=0.19$; tissue, median, $16.3 \%, \mathrm{p}=0.35$.

blood between the groups of patients (Fig. 2). Moreover, we did not detect significant differences in the percentages of $\mathrm{CD} 4{ }^{+} / \mathrm{IL}-21^{+^{*}}(\mathrm{p}=0.7)$ and $\mathrm{CD} 4{ }^{+} / \mathrm{IL}-22^{+^{*}}(\mathrm{p}=0.8)$ Th17 cells in the ovarian tissue between the groups of patients (Fig. 3). ${ }^{*} \mathrm{CD} 4^{+} / \mathrm{IL}-21^{+}$is the sum of the percentages of $\mathrm{CD} 4^{+} / \mathrm{IL}-21^{+} /$ IL- $22^{-}$and $\mathrm{CD}^{+} / \mathrm{IL}-21^{+} / \mathrm{IL}-22^{+}$Th17 cells. ${ }^{*} \mathrm{CD} 4^{+} / \mathrm{IL}-22^{+}$is the sum of the percentages of the $\mathrm{CD}^{+} / \mathrm{IL}-21^{-} / \mathrm{IL}-22^{+}$and $\mathrm{CD} 4^{+} /$ IL-21 $/$ IL- $22^{+}$Th17 cells. The percentage of Th17 lymphocytes in peripheral blood and ovarian cancer tissues was next evaluated as a prognostic factor. The Kaplan-Meier survival analysis was performed in a group of patients with ovarian cancer. The patients were subdivided into 2 groups according to the median specificity and sensitivity: $>1.6$ or $<1.6 \%$ in the peripheral blood, and $>16.3$ and $<16.3 \%$ in ovarian cancer tissue. The result of the Mantel-Cox test was insignificant in regards to patient survival as dependent on the percentage of Th17 cells in the peripheral blood $(\mathrm{p}=0.19)$ and in tissue ovarian cancer $(\mathrm{p}=0.35)$ (Fig. $4 \mathrm{~A}$ and $\mathrm{B})$.

Concentration of interleukin-17A (IL-17A). Our results showed statistically significant differences between the analyzed groups ( $\mathrm{p}=0.001$ ) (Fig. 5). Post hoc analysis showed 


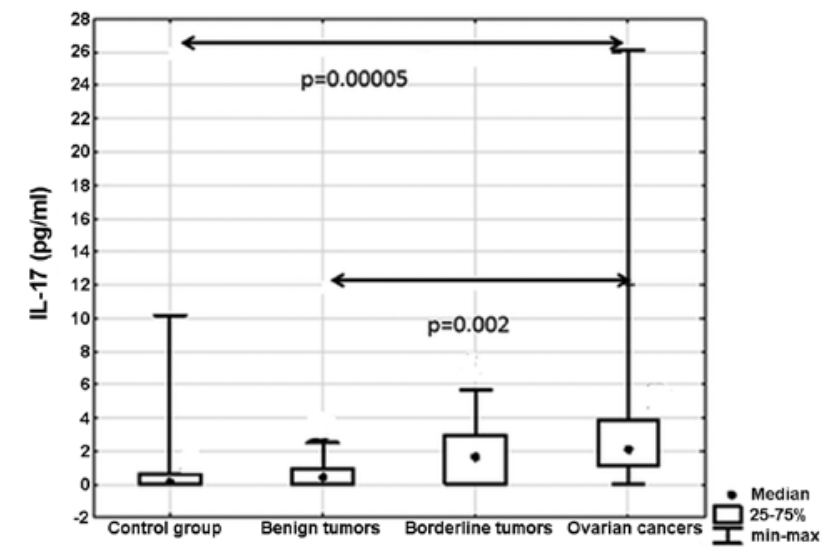

Figure 5. The concentration of IL-17A in the serum of patients with ovarian tumors. Statistical analysis using the Kruskal-Wallis test showed statistically significant differences between the analyzed groups $(\mathrm{p}=0.001)$. Post hoc analysis showed significantly higher levels of IL-17A in women with ovarian cancer compared to the group without ovarian pathology $(\mathrm{p}=0.00005)$, and between groups of women with benign and malignant tumors $(\mathrm{p}=0.002)$.

significantly higher concentrations of IL-17A in women with ovarian cancer compared to the group without ovarian pathology $(\mathrm{p}=0.00005)$ as well as that between patients with malignant and benign ovarian tumors $(\mathrm{p}=0.002)$.

Relationship between IL-17A and Th17 cell subpopulations secreting $C D 4^{+} / I L-17^{+*}, C D 4^{+} / I L-21^{+}$and $C D 4^{+} / I L-22^{+}$in peripheral blood and in the tissues of ovarian tumors. A negative correlation was found in the percentage of CD4 ${ }^{+} / \mathrm{IL}-21^{+*}$ $\left(r_{s}=-0.8, p=0.02\right)$ and CD4 ${ }^{+} / \mathrm{IL}_{-1} 7^{+*}\left(r_{\mathrm{s}}=-0.78, \mathrm{p}=0.03\right)$ in the tissue and IL-17A in blood serum of patients with borderline tumors. Moreover, a negative correlation was shown between IL-17A and the percentage of $\mathrm{CD} 4^{+} / \mathrm{IL}-21^{+*}$ in peripheral blood $\left(r_{s}=-0.48, p=0.03\right)$ in the group of patients with ovarian cancer (Fig. 6). ${ }^{*} \mathrm{CD} 4^{+} / \mathrm{IL}-21^{+}$is the sum of the percentages of $\mathrm{CD}^{+} / \mathrm{IL}-21^{+} / \mathrm{IL}-22^{-}$and $\mathrm{CD} 4^{+} / \mathrm{IL}-21^{+} / \mathrm{IL}-22^{+}$Th17 cells. ${ }^{*} \mathrm{CD} 4^{+} / \mathrm{IL}^{-17^{+}}$is the sum of the percentages of $\mathrm{CD}^{+} /$

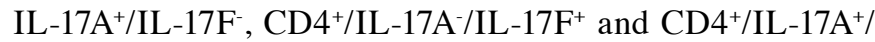
IL-17F ${ }^{+}$Th 17 cells

Prognostic value of IL-17A in ovarian cancer patients. The patients were divided into 2 groups according to the median value of IL-17A ( 5 women with $>0.87 \mathrm{pg} / \mathrm{ml}$ and 19 women with $<0.87 \mathrm{pg} / \mathrm{ml})$. The result of the Mantel-Cox test was not significant $(\mathrm{p}=0.6)$ (Fig. 7).

\section{Discussion}

The multiparameter analysis of cytokines secreted by Th17 cells has not been previously performed. Currently we focused on the determination of the capacity of these cells to secrete IL-17 with separation into isoforms. Moreover, we assessed not only two isoforms of IL-17 (A and F), but also IL-21 and IL-22.

The phenotypes, distribution in tissues and profile of the secreted cytokines in ovarian tumors have not yet been fully explored. We found that the distribution of the different subpopu-

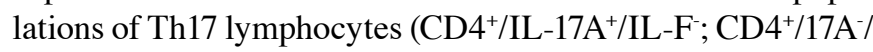
$\mathrm{IL}_{-} \mathrm{F}^{+}, \mathrm{CD}^{+} / \mathrm{IL}-17 \mathrm{~A}^{+} / \mathrm{IL}_{-} \mathrm{F}^{+}, \mathrm{CD}^{+} / \mathrm{IL}^{-17^{+}}, \mathrm{CD}^{+} / \mathrm{IL}^{-} 1^{+}$and $\mathrm{CD}^{+} / \mathrm{IL}^{-22^{+}}$) in peripheral blood in non-malignant, border-
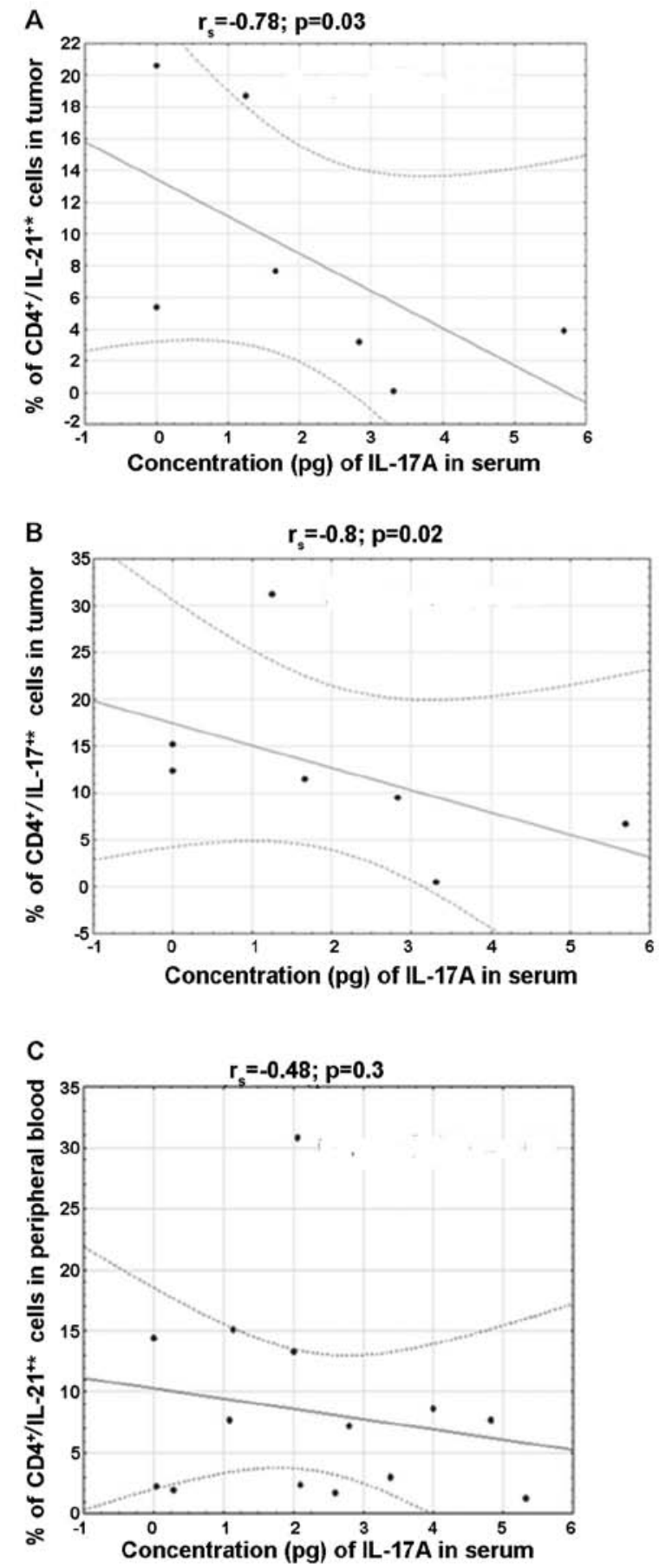

Figure 6. Relationship between the concentration of IL-17A in serum and lymphocyte Th17 in the studied groups. (A) The relationship between the concentration of IL-17A and the percentage of $\mathrm{CD}^{+} / \mathrm{IL}-21^{+*}$ in tissue of tumors in the group of patients with borderline tumors; $r_{s}=-0.78, p=0.03$. ${ }^{*} \mathrm{CD} 4^{+} / \mathrm{IL}-21^{+}$is a sum of the percentages of $\mathrm{CD}^{+} / \mathrm{IL}-21^{+} / \mathrm{IL}-22^{-}$and $\mathrm{CD} 4^{+} /$ IL-21 $1^{+} / \mathrm{IL}-22^{+}$Th17 cells. (B) The relationship between the concentration of IL-17A and the percentage of $\mathrm{CD} 4^{+} / \mathrm{IL}-17^{+*}$ in tumor tissues in a group of patients with borderline tumors; $\mathrm{r}_{\mathrm{s}}=-0.8, \mathrm{p}=0.02 .{ }^{*} \mathrm{CD} 4^{+} / \mathrm{IL}-17^{+}$, is a sum of

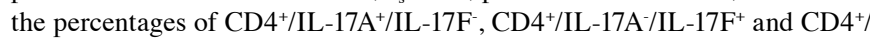
IL-17A ${ }^{+} /$IL-17F ${ }^{+}$Th17 cells. (C) Relationship between the concentration of IL-17A and the percentage of CD $4^{+} / \mathrm{IL}-21^{+^{*}}$ in the peripheral blood in a group of patients with ovarian cancer; $\mathrm{r}_{\mathrm{s}}=-0.48, \mathrm{p}=0.03$. ${ }^{*} \mathrm{CD} 4^{+} / \mathrm{IL}-21^{+}$is the sum of the percentages of $\mathrm{CD}^{+} / \mathrm{IL}-21^{+} / \mathrm{IL}-22^{-}$and $\mathrm{CD} 4^{+} / \mathrm{IL}-21^{+} / \mathrm{IL}-22^{+}$Th17 cells.

line (BOT) and malignant tumor tissues were not significantly different in women compared to patients without ovarian pathology. There were no significant differences between 


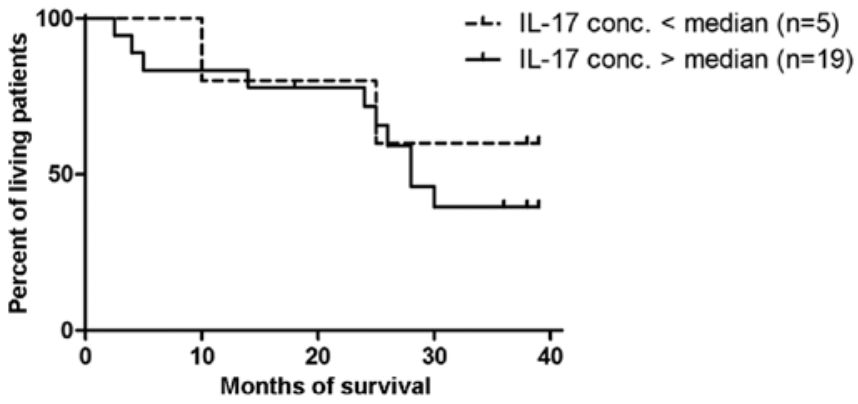

Figure 7. Kaplan-Meier survival curve depending on the concentration of IL-17A in the serum of patients with ovarian cancer. Median, $0.87 \mathrm{pg} / \mathrm{ml}$, $\mathrm{p}=0.6$.

these parameters in terms of Th17 cell proportion, although, a higher concentration of Th17 cells in the tissue was observed, similarly to Kryczek et al (9). The authors demonstrated that the percentage of Th17 cells in the CD4 lymphocytes in tumor tissue was significantly higher compared to peripheral blood. The increased concentration of Th17 in a tissue and their migration to the tumor may be associated with a high expression of CXCR4, CCR6 and CD161 (9). Moreover, it is important to know the functions and interactions beetwen IL-17F and IL-17A in the neoplastic microenviroment at both the molecular and cellular levels. Understanding these relationships may provide a new strategy for systemic anticancer therapy, particularly for ovarian cancer patients.

Kryczek et al (9) also analyzed the relationship between the percentage of Th17 cells and other immune cell subpopulations. They observed an inverse correlation between Th17 and Treg lymphocytes. Tregs have high expression of CD39 (ectonucleotidase), which converts ATP into adenosine. They suggested that the development of Th17 cells is inhibited by Tregs through the adenosinergic pathway. Ye et al (10) noted that the cells from each line of development may be interconverted in the tumor microenvironment by acquiring different functions. Th17 lymphocytes that transform into IFN $-\gamma^{+} \mathrm{FOXP} 3^{+} \mathrm{T}$ cells acquire potent immunosuppressive properties. This conversion is possibly part of the tumor escape strategy against cells of the immune system. Fialová et al (11) found an increased recruitment of Th17 cells in women at the early clinical stages of ovarian cancer, while the decreased migration of Tregs was observed in patients affected by advanced disease.

Miyahara et al (12) suggested that a low concentration of Th17 cells, and a high concentration of Tregs is associated with elevated concentrations of TGF- $\beta$ cytokines in the tumor. They found that tumor cells secrete large amount of the latent form of TGF- $\beta$ (inactive). However, the level of the active form of TGF was very low due to its short half-life. In addition, TGF- $\beta$ may be present in the free form and in the form of membrane-bound Tregs. Increased percentage of Tregs and reduced Th17 cells in the tumor supported the view that these cells mutually regulate the presence of other cytokines in the tumor microenvironment $(8,11)$. However, the molecular mechanisms underlying the formation and mutual regulation of Treg and Th17 cells in the tumor microenvironment remains unknown.
There is increasing evidence suggesting that Th17 cells protect against cancer development in several manners. Firstly, tumor-infiltrating Th17 cells express several effector cytokines, similar to those detected in patients affected by infectious diseases. This suggests that Th17 cells infiltrating the tumor may be functionally similar to T effector cells. In accordance with this possibility, Th17 cells are negatively correlated with the presence of Tregs and are positively correlated with effector cells secreting IFN- $\gamma$, cytotoxic $\mathrm{CD}^{+}$and NK cells, in the same tumor microenvironment. Secondly, Muranski et al reported a protective role of Th17 cells during carcinogenesis (13). Transgenic T cells with a Th17 phenotype after treatment with TGF- $\beta$ and IL- 6 induced tumor eradication in mice. Furthermore, mice deficient in IL-17 showed accelerated tumor growth and lung metastases in several cancer models. Tumor-infiltrating Th17 lymphocytes do not produce granzyme B and perforin; therefore, Th17 cells do not act as intermediaries in direct cytotoxic activity against tumor cells (3). Instead, Th17 cells recruit other effector cells of the immune system. According to this hypothesis, IL-17 and INF- $\gamma$ derived from Th17 cells synergistically induce the production of CXCL9 and the chemokine CXCL10 by tumor cells, which in turn promotes the migration of effector $\mathrm{T}$ lymphocytes into the compartment (3). CXCL9 and CXCL10 levels were found to be directly correlated with the number of $\mathrm{CD}^{+}$tumor-infiltrating and NK cells. Th17 lymphocytes stimulate tumor cells to secrete CCL20, which recruits dendritic cells into the tumor microenvironment. These data strongly support the view that Th17 cells play an indirect role in antitumor immunity through the promotion of effector T cells, NK and dendritic cells (7).

There is strong evidence demonstrating the role of IL-17 secreted by Th17 cells in the promotion of carcinogenesis. IL-17 induces IL- 6 production by tumor cells and stromal cells. IL-6 activates STAT3, which increases the level of genes facilitating tumor progression and the development of metastasis (7). Tartour et al (14) reported that transfection with IL-17 of human cervical cancer cells increased tumor growth when transplanted into nude mice. In addition, mice lacking $I L-17$ demonstrated reduced tumor growth of B16 melanoma and MB49 bladder cancer, suggesting a role of IL-17 in promoting tumor growth (14).

Kryczek et al (9) also demonstrated a correlation between the percentage of Th17 cells and patient survival time. In patients whose peritoneal fluid contained high concentrations of IL-17, the average survival time was 78 months. In turn, patients with decreased levels of IL-17 in peritoneal fluid lived significantly shorter (27 months). Opposite data were published by Lan et al (15) who found that high IL-17 expression was correlated with improved progression-free survival in advanced stage ovarian cancer patients. No significant difference was observed in overall survival between the high and low IL-17 expression groups (15). In the present study, the decreased percentage of Th17 cells $\left(\mathrm{CD} 4^{+} / \mathrm{IL}-17^{+*}\right)$ in the tumor microenvironment did not correlate with a reduced survival time of patients affected by ovarian cancer, probably due to advanced stage of the ovarian cancer group.

The next step of the research was to assess the proportion of Th17 lymphocytes secreting IL-21 and IL-22. The percentages of $\mathrm{CD}^{+} / \mathrm{IL}-21^{+} / \mathrm{IL}-22^{-}, \mathrm{CD} 4^{+} / \mathrm{IL}-21^{-} / \mathrm{IL}-22^{+}$, $\mathrm{CD}^{+} / \mathrm{IL}-21^{+} / \mathrm{IL}_{-} 22^{+}, \mathrm{CD} 4^{+} / \mathrm{IL}-21^{+}$and $\mathrm{CD} 4{ }^{+} / \mathrm{IL}-22^{+} \mathrm{Th} 17$ 
cells in peripheral blood and tissue did not significantly differ among the groups. Moreover, a significant correlation was found between $\mathrm{CD} 4 / / \mathrm{IL}-21^{+}$in peripheral blood and IL-17A in the group of women with ovarian cancer. IL-21 is produced predominantly by Th17 and NKT cells. In cooperation with TGF- $\beta$ it induces the differentiation of T cells towards the Th17 phenotype. It also participates in the mutual regulation of Th17 and Treg cells. In certain circumstances, IL-21 may exert anti-inflammatory effects due to its ability to inhibit dendritic cell maturation and stimulation of IL-10 (15). In this context, IL-21 stimulates an immune response against tumor cells and promotes a $\mathrm{CD} 8^{+} \mathrm{T}$ cell response against viruses $(16,17)$. Immunostimulatory activity of IL-21 may be possibly applied as a potential immunotherapeutic agent for the treatment of human cancers. Neutralization of IL-22 may reduce metastasis, chemoresistance, and inflammation associated with cancer. Given that IL-2 BP is a specific natural antagonist of IL-22, it may be a prime candidate as an anti-IL-22 therapy. Anti-TNF drugs such as adalimumab, etanercept and infliximab transiently decrease IL-22 expression, likely since Th22 cells depend on TNF for differentiation. The anti-IL-6 antibody toclizumab may also suppress the differentiation of both Th17 and Th22 cells. A neutralizing antibody against IL-12p40, ustekinumab, is able to target both IL-12 and IL-23 and therefore prevent the differentiation of Th1, Th17 and Th22 cells, eliminating sources of IL-22 (18-20). However, the nature and clinical relevance of IL-22+ cells is poorly defined in patients affected by ovarian cancer.

Xiang et al (21) reported that IL-17 contributed to ovarian cancer malignancy by promoting the self-renewal of $\mathrm{CD} 133^{+}$ cancer stem cells and IL-17. They showed by recombinant human IL-17 stimulation and IL-17 transfection that the growth and sphere formation capacities of $\mathrm{CD}_{133^{+}}$ovarian cancer stem cells were significantly enhanced in a dosedependent manner increasing the tumorigenesis capacity in nude mice. These data suggest that the IL-17 signaling pathway may serve as a therapeutic target for patients with ovarian cancer. Kryczek et al (22) also revealed a relationship between a key transcription factor (STAT3) and an important epigenetic marker (H3K79) in determining cancer stemness and tumorigenesis.

Our previous data revealed that the percentage of Th17 cells in peritoneal fluid (PF) corresponds with the severity of endometriosis (23). The percentage of Th17 lymphocytes in PF was significantly higher in patients with moderate/ severe endometriosis compared to patients with a minimal/ mild form of the disease (23). Continuing with our research we demonstrated a higher percentage of Th17 cells in tissue than in peripheral blood and a negative correlation between $\mathrm{CD} 4^{+} / \mathrm{IL}-17^{+}$lymphocytes and the concentration of IL-17A in patients with ovarian cancer, thus that IL-21 could adjust Th17 differentiation. The generation of Th17 cells in the conventional manner is attenuated by blocking IL-21. This cytokine is capable of acting on Th17 cells in an autocrine manner in response to antigen stimulation (24).

In conclusion, we showed that more Th17 cells secreted IL-17A and IL-21 in the tissues of borderline ovarian tumors and less IL-17A in serum. We also observed that in peripheral blood of patients with ovarian cancer, a higher percentage of Th17 lymphocytes was negatively correlated with a lower concentration of IL-17A in serum. An increased percentage of Th17 cells in ovarian tissue did not influence the survival time of patients with ovarian cancer.

\section{Acknowledgements}

The permission to conduct the present study was obtained from the Bioethics Committee of the Medical University in Lublin (no. KE-0254/90/2011). Funding for the present study was supported by the grant MNsd 410/2011.

\section{References}

1. Romagnani S: Human Th17 cells. Arthritis Res Ther 10: 206, 2008.

2. Iwakura Y, Nakae S, Saijo S and Ishigame H: The roles of IL-17A in inflammatory immune responses and host defense against pathogens. Immunol Rev 226: 57-79, 2008.

3. Søndergaard H and Skak K: IL-21: Roles in immunopathology and cancer therapy. Tissue Antigens 74: 467-479, 2009.

4. Geboes L, Dumoutier L, Kelchtermans H, Schurgers E, Mitera T, Renauld JC and Matthys P: Proinflammatory role of the Th17 cytokine interleukin-22 in collagen-induced arthritis in C57BL/6 mice. Arthritis Rheum 60: 390-395, 2009.

5. Zenewicz LA and Flavell RA: IL-22 and inflammation: Leukin' through a glass onion. Eur J Immunol 38: 3265-3268, 2008.

6. Duhen T, Geiger R, Jarrossay D, Lanzavecchia A and Sallusto F: Production of interleukin 22 but not interleukin 17 by a subset of human skin-homing memory T cells. Nat Immunol 10: 857-863, 2009.

7. Martin-Orozco N, Muranski P, Chung Y, Yang XO, Yamazaki T, Lu S, Hwu P, Restifo NP, Overwijk WW and Dong C: T helper 17 cells promote cytotoxic $\mathrm{T}$ cell activation in tumor immunity. Immunity 31: 787-798, 2009.

8. Wang L, Yi T, Kortylewski M, Pardoll DM, Zeng D and Yu H: IL-17 can promote tumor growth through an IL-6-Stat 3 signaling pathway. J Exp Med 206: 1457-1464, 2009.

9. Kryczek I, Banerjee M, Cheng P, Vatan L, Szeliga W, Wei S, Huang E, Finlayson E, Simeone D, Welling TH, et al: Phenotype, distribution, generation, and functional and clinical relevance of Th17 cells in the human tumor environments. Blood 114: 1141-1149, 2009.

10. Ye J, Su X, Hsueh EC, Zhang Y, Koenig JM, Hoft DF and Peng G: Human tumor-infiltrating Th17 cells have the capacity to differentiate into IFN- $\gamma^{+}$and FOXP3 ${ }^{+}$T cells with potent suppressive function. Eur J Immunol 41: 936-951, 2011.

11. Fialová A, Partlová S, Sojka L, Hromádková H, Brtnický T, Fučíková J, Kocián P, Rob L, Bartůňková J and Spíšek R: Dynamics of T-cell infiltration during the course of ovarian cancer: The gradual shift from a Th17 effector cell response to a predominant infiltration by regulatory T-cells. Int J Cancer 132: 1070-1079, 2013.

12. Miyahara Y, Odunsi K, Chen W, Peng G, Matsuzaki J and Wang RF: Generation and regulation of human CD4 ${ }^{+}$ IL-17-producing T cells in ovarian cancer. Proc Natl Acad Sci USA 105: 15505-15510, 2008.

13. Muranski P, Boni A, Antony PA, Cassard L, Irvine KR, Kaiser A, Paulos CM, Palmer DC, Touloukian CE, Ptak K, et al: Tumor-specific Th17-polarized cells eradicate large established melanoma. Blood 112: 362-373, 2008.

14. Tartour E, Fossiez F, Joyeux I, Galinha A, Gey A, Claret E, Sastre-Garau X, Couturier J, Mosseri V, Vives V, et al: Interleukin 17, a T-cell-derived cytokine, promotes tumorigenicity of human cervical tumors in nude mice. Cancer Res 59: 3698-3704, 1999.

15. Lan C, Huang X, Lin S, Huang H, Cai Q, Lu J and Liu J: High density of IL-17-producing cells is associated with improved prognosis for advanced epithelial ovarian cancer. Cell Tissue Res 352: 351-359, 2013.

16. Brandt K, Bulfone-Paus S, Foster DC and Rückert R: Interleukin-21 inhibits dendritic cell activation and maturation. Blood 102: 4090-4098, 2003.

17. Veldhoen M, Hirota K, Westendorf AM, Buer J, Dumoutier L, Renauld JC and Stockinger B: The aryl hydrocarbon receptor links $\mathrm{T}_{\mathrm{H}}$ 17-cell-mediated autoimmunity to environmental toxins. Nature 453: 106-109, 2008. 
18. Huber S, Gagliani N, Zenewicz LA, Huber FJ, Bosurgi L, Hu B, Hedl M, Zhang W, O'Connor W Jr, Murphy AJ, et al: IL-22BP is regulated by the inflammasome and modulates tumorigenesis in the intestine. Nature 491: 259-263, 2012.

19. Sabat R, Ouyang W and Wolk K: Therapeutic opportunities of the IL-22-IL-22R1 system. Nat Rev Drug Discov 13: 21-38, 2014

20. Caproni M, Antiga E, Melani L, Volpi W, Del Bianco E and Fabbri P: Serum levels of IL-17 and IL-22 are reduced by etanercept, but not by acitretin, in patients with psoriasis: A randomized-controlled trial. J Clin Immunol 29: 210-214, 2009.

21. Xiang T, Long H, He L, Han X, Lin K, Liang Z, Zhuo W, Xie R and Zhu B: Interleukin-17 produced by tumor microenvironment promotes self-renewal of CD133+ cancer stem-like cells in ovarian cancer. Oncogene 34: 165-176, 2015.
22. Kryczek I, Lin Y, Nagarsheth N, Peng D, Zhao L, Zhao E, Vatan L, Szeliga W, Dou Y, Owens S, et al: IL- $22^{+} \mathrm{CD} 4^{+} \mathrm{T}$ cells promote colorectal cancer stemness via STAT3 transcription factor activation and induction of the methyltransferase DOT1L. Immunity 40: 772-784, 2014

23. Gogacz M, Winkler I, Bojarska-Junak A, Tabarkiewicz J, Semczuk A, Rechberger T and Adamiak A: Increased percentage of Th17 cells in peritoneal fluid is associated with severity of endometriosis. J Reprod Immunol 117: 39-44, 2016.

24. Wei L, Laurence A, Elias KM and O'Shea JJ: IL-21 is produced by Th17 cells and drives IL-17 production in a STAT3-dependent manner. J Biol Chem 282: 34605-34610, 2007. 